\title{
Implementasi Konvensi Internasional Tentang Perlindungan Hak Pekerja Asing dan Anggota Keluarganya: Studi Kasus Penjaminan Hak Pekerja Migran Indonesia di Singapura
}

\author{
Khairur Rizki ${ }^{1}$ \\ Universitas Mataram
}

\begin{abstract}
The International Convention on the Protection of the Rights of All Migrant Workers and Members of Their Families is an International Convention on the protection of the rights of foreign workers and their family members, an international convention enacted on June 1 , 2003. This convention gives equal rights to migrant workers and local workers in a country. These rights can include the right to travel, the right to transfer of work, the right to gather with family, the right to organize, and the right of recognition of those who have documents or are undocumented. By ratifying the convention, a country must give its commitment in fulfilling the rights of foreign workers and their families. Indonesia as a country that sends many workers has an obligation to ratify this convention. The concept used by the author for this article is the concept of the rights of foreign workers which can also be called migrant workers' rights. This concept itself is a derivative of the great concept of Human Rights. This research uses descriptive qualitative analysis methods in which authors combine the content of international conventions and regulations in Indonesia as primary data with library studies such as journals, and scientific articles. This article aims to find out whether or not Indonesia succeeds as a country that has ratified the convention. In addition, the authors will also analyze one case related to migrant workers from Indonesia and how the role of Indonesia protects the migrant workers. At the end of the study, the authors found the results of an analysis that until now Indonesia has not been able to solve problems related to the fulfillment of the rights of foreign workers from Indonesia.
\end{abstract}

Keywords : Convention, Rights of Foreign Workers, Migrant Workers, Indonesia

\begin{abstract}
Abstrak
International Convention On The Protection Of The Rights Of All Migrant Workers And Members Of Their Families adalah sebuah Konvensi Internasional tentang perlindungan hak pekerja asing dan anggota keluarganya, merupakan sebuah konvensi internasional yang diberlakukan pada tanggal 1 Juni 2003. Konvensi ini memberikan keadilan hak yang sama untuk pekerja migran dan pekerja lokal disuatu negara. Hak tersebut dapat berupa hak untuk berpergian, hak untuk pindah kerja, hak untuk berkumpul dengan keluarga, hak untuk berorganisasi, serta hak pengakuan terhadap yang mempunyai dokumen maupun tidak berdokumen. Dengan meratifikasi konvensi tersebut, maka sebuah negara harus memberikan komitmennya dalam memenuhi hak pekerja asing dan keluarganya. Indonesia sebagai sebuah negara yang banyak mengirim pekerja memiliki kewajiban untuk meratifikasi konvensi ini. Konsep yang digunakan penulisa untuk artikel ini adalah konsep hak pekerja asing yang juga dapat disebut dengan hak buruh migran. Konsep ini sendiri merupakan
\end{abstract}

\footnotetext{
${ }^{1}$ krizki@unram.ac.id
} 
Implementasi Konvensi Internasional Tentang Perlindungan Hak Pekerja Asing dan Anggota Keluarganya: Studi Kasus Penjaminan Hak Pekerja Migran Indonesia di Singapura

turunan dari konsep besar Hak Asasi Manusia. Penelitian ini menggunakan metode analisis kualitatif bersifat deskriptif dimana penulis mengkombinasikan isi dari konvensi internasional dan regulasi di Indonesia sebagai data primer dengan studi pustaka seperti buku jurnal, dan artikel ilmiah. Artikel ini bertujuan untuk mengetahui berhasil atau tidaknya Indonesia sebagai sebuah negara yang telah meratifikasi konvensi. Selain itu penulis juga akan menganalisis satu kasus terkait pekerja migran asal Indonesia dan bagaiaman peran Indoneisa melindungi pekerja migran tersebut. Di akhir penelitian, penulis menemukan hasil analisis dimana sampai saat ini Indonesia masih belum dapat menyelesaikan masalah - masalah terkait pemenuhan hak pekerja asing asal Indonesia.

Kata Kunci : Konvensi, Hak Pekerja Asing, Pekerja Migran, Indonesia

\section{Pendahuluan}

Perpanjangan tangan pemerintah Indonesia diluar wilayah Negara Indonesia adalah perwakilan-perwakilan Pemerintah Republik Indonesia, yang mana perwakilan-perwakilan tersebut memiliki kewajiban untuk memupuk persatuan dan kerukunan antara sesama warga negara Indonesia di luar negeri serta wajib memberikan pengayoman, perlindungan dan bantuan hukum bagi warga negara dan badan hukum Indonesia diluar negeri. Dalam hal warga negara Indonesia yang terancam bahaya nyata, Perwakilan Republik Indonesia berkewajiban memberikan perlindungan, membantu dan menghimpun mereka diwilayah yang aman, serta mengusahakan untuk memulangkan mereka ke Indonesia atas biaya Negara.

Dalam konsep human security, negara tetap memiliki tanggung jawab yang besar terhadap keamanan individu. Sebagai subjek Hukum Internasional, negara memiliki hak dan kewajiban internasional. Adapun hak dan kewajiban negara terhadap individu pada hakekatnya ditentukan oleh wilayah negara tersebut dan kewarganegaraan dari individu yang bersangkutan. Menurut pendapat Sugeng Istanto, semua orang yang berada di wilayah suatu negara baik itu warganegaranya sendiri maupun orang asing harus tunduk kepada kekuasaan dan hukum negara tersebut. Meskipun untuk imigran akan berlaku beberapa pengecualian, seperti tidak mempunyai hak dalam pemilihan umum dan tidak berhak menduduki jabatan tertentu, hal ini dapat dimengerti karena imigran juga tunduk pada hukum negara asalnya, namun dilain pihak, negara juga mempunyai kewajiban untuk melindungi 
warga negaranya yang tinggal atau berada diluar negeri. Hal tersebut sesuai dengan prinsip kewarganegaraan pasif yang menetapkan bahwa suatu negara mempunyai yuridiksi atas orang yang melakukan pelanggaran hukum di wilayah negara lain, yang akibat hukumnya menimpa warga negaranya. Oleh karena itu, jika negara tempat tejadinya pelanggaran tidak mampu dan tidak mau menghukum pelaku pelanggaran, maka negara yang warga negaranya dirugikan berwenang untuk menghukum.

Berbicara mengenai pekerja asing, tentu tak lepas dari bahaya-bahaya tindakan eksploitasi. Hal ini membuat negara berkewajiban memberi perlindungan terhadap warga negara asing dan warga negaranya sendiri yang berada di luar negeri. Perlindungan-perlindungan tersebut dapat berupa sebuah perjanjian bersama yang berlaku secara global, sehingga negara-negara yang meratifikasinya mempunyai dasar hukum yang sah untuk dapat melindungi dan member pembelaan terhadap para pekerja asing.

Konvensi Internasional tentang perlindungan hak semua buruh migran atau sering disebut International Convention on the Protection of the Rights of All Migrant Workers And The Members of Their Families (ICRMW) merupakan konvensi yang sudah ada sejak lama. Hukum Internasional konvensional diturunkan melalui perjanjian-perjanjian internasional yang kemudian disepakati oleh beberapa negara yang terlibat di dalam perjanjian tersebut. Perjanjian bisa berupa hal terkecil selama hal tersebut tidak berlawanan dengan hukum internasional. Kemudian, perjanjian tersebut menciptakan hukum yang terlibat dalam kesepakatan tersebut. Konvensi ini menentukan hak asasi manusia yang tercantum dalam Kovenan Internasional tentang Hak Ekonomi, Sosial dan Budaya dan Kovenan Internasional tentang Hak Sipil dan Politik dan secara eksplisit menyatakan bagaimana berbagai hak berbeda berlaku untuk berbagai kategori migran yang bekerja. Di luar batasan yang sudah ada yang dinyatakan oleh hukum, Konvensi tidak memiliki ketentuan yang membatasi hak negara untuk memutuskan prosedur imigrasi.

Konvensi mengenai perlindungan hak buruh migran sudah ada sejak 18 Desember 1990 dan mulai diberlakukan pada tanggal 1 Juni 2003. Dilatar belakangi oleh banyaknya pekerja asal Afrika yang diangkut secara ilegal ke Eropa dan 
Implementasi Konvensi Internasional Tentang Perlindungan Hak Pekerja Asing dan Anggota Keluarganya: Studi Kasus Penjaminan Hak Pekerja Migran Indonesia di Singapura

menghadapi situasi perbudakan dan kerja paksa yang kian hari makin memburuk. Sejak saat itu perhatian terhadap jaminan hak- hak pekerja migran mulai menjadi perhatian. Penyusunan naskah konvensi mengenai perlindungan hak- hak seluruh pekerja migran dan anggota keluarganya dimulai dan selesai pada tahun 1990. Konvensi ini ditandatangani oleh 33 negara dan 45 negara dengan status aksesi. Artinya 33 negara telah sepakat menandatangani konvensi sedangkan 45 negara tidak ikut dalam penandatanganan namun mereka terlibat dan terikat dalam konvensi tersebut. Berdasarkan Konvensi Internasional Pasal 2 (1) yang dimaksud pekerja migran yaitu mengacu pada seseorang yang akan, tengah ataupun telah melakukan pekerjaan yang dibayar dalam suatu negara dimana ia bukan menjadi warga negara. Kemudian Pasal 4 dalam Konvensi tersebut menjelaskan yang dimaksud "keluarga" yaitu mengacu pada orang yang terikat pernikahan dengan pekerja migran. Hingga pada tanggal 16 Mei 2019, sebanyak 54 negara telah meratifikasi konvensi ini. Namun konvensi ini belum ditandatangani oleh negara industri mana pun dengan imigran di dunia barat, termasuk Swiss.

Konvensi ini mensyaratkan minimal ada 20 negara ya meratifikasi sebelum dapat diberlakukan. Ketika El Salvador dan Guatemala meratifikasinya pada 14 Maret 2003, ambang batas ini tercapai. Kemudian, pada Oktober 2018, telah tercatat 54 negara berikut telah meratifikasi Konvensi, yaitu Albania, Argentina, Aljazair, Azerbaijan, Bangladesh, Belize, Bolivia, Benin, Bosnia dan Herzegovina, Burkina Faso, Tanjung Verde, Chili, Kolombia, Kongo-Brazzaville, Timor Timur, Ekuador, Mesir, El Salvador, Gambia, Ghana, Guatemala, Guyana, Guinea, Guinea-Bissau, Honduras, Indonesia, Jamaika, Kirgistan, Lesotho, Libya, Madagaskar, Mali, Mauritania, Meksiko, Maroko, Mozambik, Nikaragua, Niger, Nigeria, Paraguay, Peru, Filipina, Rwanda, Sao Tome dan Principe, Senegal, Seychelles, Sri Lanka, Saint Vincent dan Grenadines, Suriah, Tajikistan, Turki, Uganda, Uruguay, dan Venezuela.

Selain itu, beberapa negara telah menandatangani Konvensi tetapi belum meratifikasinya. Ini berarti bahwa pemerintah mereka telah menyatakan niat untuk mematuhi Konvensi tetapi belum terikat untuk melakukannya oleh hukum 
internasional. Negara-negara ini adalah: Armenia, Benin, Kamboja, Kamerun, Chad, Komoro, Gabon, Haiti, Liberia, Palau, Serbia dan Montenegro (sekarang berlaku secara terpisah untuk Serbia dan Montenegro ), Sierra Leone, dan Togo. Sejauh ini, negara-negara yang telah meratifikasi Konvensi tersebut terutama merupakan negara asal migran (seperti Meksiko, Maroko, dan Filipina). Untuk negara-negara ini, Konvensi adalah kendaraan penting untuk melindungi warganya yang tinggal di luar negeri. Di Filipina, misalnya, ratifikasi Konvensi terjadi dalam konteks yang ditandai dengan beberapa kasus pekerja Filipina dianiaya di luar negeri: kasus-kasus seperti itu merugikan penduduk Filipina dan mendorong ratifikasi Konvensi. Namun, negara-negara ini juga merupakan negara transit dan tujuan, dan Konvensi ini melukiskan tanggung jawab mereka untuk melindungi hak-hak migran di wilayah mereka. Perlu diketahui bahwa tidak ada negara penerima migran di Eropa Barat atau Amerika Utara yang telah meratifikasi Konvensi ini. Negara penerima penting lainnya, seperti Australia, negara-negara Arab di Teluk Persia, India dan Afrika Selatan belum meratifikasi Konvensi ini.

Prinsip utama konvensi ini adalah prinsip non diskriminasi. Hal tersebut diatur dalam pasal 7 Konvensi Internasional yang menyatakan bahwa negara-negara yang terlibat dalam perjanjian dan sesuai dengan instrumen internasional tentang hak asasi manusia bahwa mereka harus menghormati, menghargai, dan mematikan bahwa pekerja migran dan keluarganya berada dalam wilayahnya dan dipastikan untuk tunduk pada yurisdiksinya agar memperoleh hak sebagaimana mestinya yang diatur dalam konvensi tersebut. Setiap orang pasti mempunya hak mulai dari menyampaikan aspirasi mereka sampai hak untuk kebebasan untuk memilih pekerjaan mereka seperti yang diatur dalam pasal 23 Deklarasi Universal Hak Asasi Manusia (DUHAM). Pasal tersebut menjelaskan tentang setiap orang mempunyai hak untuk mendapatkan upah yang adil dan menguntungkan serta memberikan jaminan yang baik untuk dirinya dan keluarganya. Pekerjaan dapat dipilih secara bebas, pendapatan yang ia dapatkan harus diberikan dengan baik dan sesuai. Sejak lama, DUHAM juga telah mengatur dan memberi penegasan mengenai hak-hak untuk mendapatkan sebuah pekerjaan serta perlindungan dalam dunia kerja juga 
Implementasi Konvensi Internasional Tentang Perlindungan Hak Pekerja Asing dan Anggota Keluarganya: Studi Kasus Penjaminan Hak Pekerja Migran Indonesia di Singapura

tidak kalah pentingnya. Maka diskriminasi dalam bentuk apapun dianggap bertentangan dengan dengan prinsip-prinsip HAM.

Selain itu, konvensi ini memberikan keadilan hak yang sama untuk pekerja migran dan pekerja lokal disuatu negara. Hak tersebut dapat berupa hak untuk berpergian, hak untuk pindah kerja, hak untuk berkumpul dengan keluarga, hak untuk berorganisasi, serta hak pengakuan terhadap yang mempunyai dokumen maupun tidak berdokumen. Namun konvensi ini tidak mencantumkan serangkaian hak-hak baru yang secara eksklusif bagi pekerja migran beserta anggota keluarganya. Seperti di dalam pasal di Bagian III, menyatakan ulang dan menekankan pemberlakuan untuk pekerja migran dan anggota keluarganya terhadap hak-hak relevan yang dicantumkan di dalam Kovenan Internasional mengenai Hak Sipil dan Hak Politik dan Kovenan Internasional mengenai Hak Ekonomi, Hak Sosial, dan Hak Budaya dan perjanjian-perjanjian hak asasi utama lainnya. Namun Konvensi ini mencantumkan sejumlah hak yang membutuhkan perlindungan khusus dan memberikan jaminan tambahan mengingat kerentanan khusus pekerja migran dan anggota keluarganya banyak terjadi. Adapun konvensi ini tidak berlaku bagi :

a. Orang-orang yang dikirim atau dipekerjakan oleh organisasi dan badan-badan internasional, atau oleh suatu Negara di luar 7 wilayahnya untuk menjalankan tugas resmi, yang kedatangan dan statusnya diatur oleh hukum internasional umum atau oleh perjanjian internasional atau konvensi khusus;

b. Orang-orang yang dikirim atau dipekerjakan oleh suatu Negara atau atas nama Negara di luar wilayahnya, yang berpartisipasi dalam program pembangunan dan program kerja sama lain, yang kedatangan dan statusnya diatur oleh perjanjian dengan Negara tujuan kerja, dan yang sesuai dengan perjanjian tersebut, tidak dianggap sebagai pekerja migran;

c. Orang-orang yang bertempat tinggal di Negara yang berbeda dengan Negara asalnya sebagai penanam modal;

d. Pengungsi atau orang tanpa kewarganegaraan, kecuali ketentuan tentang hal ini ditetapkan dalam ketentuan hukum nasional, atau dalam instrumen internasional yang berlaku bagi Negara Pihak tersebut; 
e. Pelajar dan peserta pelatihan;

f. Pelaut dan pekerja pada suatu instalasi lepas pantai yang belum memperoleh izin tinggal dan melakukan aktivitas yang dibayar di Negara tujuan kerja.

Di Indonesia sendiri Konvensi Migran 1990 diratifikasi oleh DPR RI dan mendapatkan pengesahan tanda tangan oleh Presiden pada 12 Mei 2012. Ratifikasi tersebut diundangkan menjadi UU No.6/2012 dan Indonesia menjadi Negara ke 46 yang meratifikasi Konvensi Migran 1990. Disisi lain, dengan meratifikasi konvensi berarti pemerintah punya kewajiban untuk memberikan peluang dan kesempatan yang sama bagi pekerja migrant dan anggota keluarganya termasuk apabila mereka terkena PHK dan berkewajiban untuk memberikan tunjangan pengangguran. Konvensi ini juga mengatur permasalahan minimnya standar perlindungan hak hak sipil, ekonomi, social dan budaya pekerja migran dan anggota keluarganya, oleh karena itu Konvensi ini sebagai langkah awal untuk perbaikan menyeluruh tentang penyelenggaraan perlindungan pekerja migran. Konvensi ini mengatur beberapa hal penting, seperti:

1. Mengatur mengenai standar minimum perlindungan hak-hak sipil, politik, ekonomi, social dan budaya seluruh pekerja migran dan anggota keluarganya. Konvensi ini mendorong Negara agar menyelaraskan perundang-undangan dengan standar universal yang termasuk dalam konvensi.

2. Mengakui adanya kontribusi yang disumbangkan oleh pekerja migran terhadap ekonomi dan masyarakat Negara tempat mereka bekerja serta pembangunan Negara asal mereka.

3. Mencantumkan serangkaian Standar untuk perlindungan pekerja migran dan kewajiban Negara yang terkait, meliputi Negara asal, transit dan Negara tempat bekerja.

4. Mencegah dan menghapuskan eksploitasi seluruh pekerja migran dan anggota keluarganya di seluruh proses migrasi, termasuk mencegah terjadinya perdagangan manusia. 
Implementasi Konvensi Internasional Tentang Perlindungan Hak Pekerja Asing dan Anggota Keluarganya: Studi Kasus Penjaminan Hak Pekerja Migran Indonesia di Singapura

5. Konvensi ini tidak hanya melindungi para pekerja migran, tetapi juga meindungi kepentingan Negara penerima pekerja migran terkait dengan pembatasan akses kategori pekerjaan guna melindungi warga negaranya.

Hak hak dari Konvensi Inernasional ICRMW 1990 untuk pekerja migran dan anggota keluarganya adalah melindungi kepentingan para pekerja migran yang mereka dipekerjakan di Negara-nagara yang bukan Negaranya sendiri, Mengakui pentingnya pekerjaan yang telah dilakukan sehubungan dengan buruh migran dan anggota keluarganya. Dalam konvensi ini Hak hak pekerja migran dan keluarganya utamanya seperti konvensi konvensi yang lainnya untuk melindungi hak dari diri manusia mereka, agar tidak terjadi hal yang bisa dikatakan melanggar HAM karena konteks dalam konvensi ini adalah manusia yang bekerja di Negara lain, dan tentu saja hal tersebut akan mengakibatkan hal yang tak diinginkan misalnya pembunuhan, penjualan manusia, dihiraukan oleh pemerintah maupun masyarakat hanya karena mereka dari Negara dan bahasa yang berbeda. Jadi konvensi ICRMW ini memfokuskan agar hak hak dari pekerja migran dan anggota keluarganya untuk setidaknya menerima kehidupan yang layak dinegara lain. Hak hak yang membahas tentang Hak Asasi Manusia dari pekerja migran dan anggota keluarganya dalam Konvensi ICRMW 1990 ini terdapat dibeberapa pasal tentang bagaimana Negara harus mengerti hak para pekerja migran dan anggota keluarganya tersebut dijelaskan sebagai berikut.

\section{1. (Pasal $1 \mathrm{~s} / \mathrm{d}$ 6): RUANG LINGKUP DAN DEFINISI}

Bagian ini menjelaskan siapa saja yang masuk dalam kategori pekerja migran dan cakupan perlindungannya. Konvensi ini berlaku bagi seluruh pekerja migran dan anggota keluarganya tanpa membedakan apa pun seperti jenis kelamin, ras, warna kulit, bahasa, agama atau kepercayan, pendapat politik atau lainlain, kebangsaan, asal-usul etnis atau sosial, kewarganegaraan, usia, kedudukan ekonomi, kekayaan, status perkawinan, status kelahiran atau lainlain. Konvensi ini juga melingkupi seluruh pekerja migran selama proses dan 
area serta semua status migrasi, yang berdokumen maupun yang tidak berdokumen atau tak regular.

2. (Pasal 7): NON DISKRIMINASI TERKAIT HAK

Bagian ini menegaskan prinsip bahwa perlindungan dan pemenuhan hak yang dilakukan negara pihak dalam mengimplimentasikan Mengenal Konvensi PBB 1990 tentang Perlindungan Hak-Hak Seluruh Pekerja Migran dan Anggota Keluarganya (Konvensi Migran 1990), Konvensi ini sejalan dengan Konvensi HAM lain, tanpa pembedaan dan diskriminasi.

3. (Pasal 8-35): MENCAKUP HAK ASASI MANUSIA BAGI SELURUH PEKERJA MIGRAN DAN ANGGOTA KELUARGANYA

Bagian ini berisi tentang hak-hak seluruh pekerja migran dan anggota keluarnya, tanpa pembedaan, diskriminasi dan memandang status migrasinya. Namun penting diingat bahwa dengan dilindungi dan dijaminnya hak-hak pekerja migran tidak berdokumen bukan berarti mengarahkan untuk bekerja ke luar negeri dengan tidak berdokumen. Arah Konvensi ini adalah mengkondisikan perlindungan dan tata migrasi yang aman, bermartabat dan berdokumen, bagi pekerja migran berdokumen atau bermigrasi dalam situasi regular patut mendapatkan hak-hak lebih ketimbang yang tidak berdokumen.

Konvensi tentang hak pekerja migran dan segala hal yang berhubungan dengan mereka tidak lahir begitu saja. Kompleksitas sebuah negara menyebabkan kondisi dimana masyarakat terus mencari cara baru untuk bertahan hidup. Salah satunya dengan menjadi pekerja migran. Tidak terkecuali di Indonesia. Namun dalam beberapa kejadian menjadi pekerja migran sering kali mengalami diskriminasi karena faktor rasa kuasa yang dimiliki oleh pekerja mereka di luar negeri. Selain itu secara umum biasanya pekerja migran bekerja pada bidang bidang informal seperti buruh kasar, asisten rumah tangga, buruh pabrik, dan pekerjaan serupa. Steriotip yang berkembang adalah mereka yang menjadi buruh migran yang bekerja di sektor informal akan terdegradasi nilainya sebagai manusia. Perlu dilihat lebih luas lagi bahwa ketika seorangmemilih untuk menjadi pekerja migran maka banyak hal yang kemudian bergantung pada mereka termasuk 
Implementasi Konvensi Internasional Tentang Perlindungan Hak Pekerja Asing dan Anggota Keluarganya: Studi Kasus Penjaminan Hak Pekerja Migran Indonesia di Singapura

keluarga dan suadara - saudaranya dikampung. Buruh migran sendiri adalah seseorang yang akan, sedang atau telah melakukan pekerjaan yang kemudian dibayar dalam suatu negara dimana ia bukan merupakan warga negara tersebut.

Karena itu kemudian muncul konsep hak asasi buruh yang merupakan turunan dari DUHAM yang membahas tentang hak asasi manusia dari semua aspek guna untuk melindungi para buruh migran yang menajdi korban kekerasan baik fisik maupun psikologi, diskriminasi, ketidakadilan upah, dan lain - lain. ILO (International Labor Organization) dapat dikatakan yang paling getol untuk memperkenalkan hak pekerja migran sekaligus menjelaskan tentang konsep hak buruh migran. Menurut ILO hak buruh migran adalah hak - hak yang diberikan kepada pekerja migran berdasarkan kenyataan bahwa mereka adalah manusia. Dalam konsep ini juga dijelaskan bahawa hak -hak tersebut harus disediakan oleh negara - negara asal dan negara - negara tujuan buruh migran. Hal ini kemudian mengharuskan pemerintah dari negara - negara tersebut untuk menghormati, memberikan dan melindungi hak asai buruh migran.. Artinya sebuah negara memiliki tanggung jawab terhadap buruh migran.

Konsep inilah yang kemudian mendorong munculnya konvensi tentang perlindungan hak buruh/pekerja migran. Dalam ketentuannya negara - negara yang meratifikasi konvensi tersebut maka wajib untuk menghormati, memberikan, dan melindungi hak buruh migran termasuk Indonesia. Beberapa hal yang kemudian harus dipenuhi oleh negara dalam konsep hak asasi buruh migran adalah mengatur mekanisme rekrutmen, sosialisasi dan edukasi kepada calon ataupun buruh migran termasuk tentang fasilitas dan kontrak kerja, pendataan terkait segala urusan yang berhubungan dengan buruh migran, penyesuaian tujuan atau tempat kerja, dan menjamin keamanan dan keselamatan buruh migran maupun keluarganya.

Konsep tersebut kemudian menjadi acuan penulis untuk menganalisis kejadian kasus HAM yang dialami buruh migran Indonesia di Singapura. Kemudian untuk memperdalam analisis penulis mengangkat satu studi kasus riil untuk melihat bagaimana usaha pemerintah Indonesia dalam melaksanakan tanggung jawabnya terhadap buruh migran dari Indonesia. 


\section{Metode Penelitian}

Penelitian ini bersifat kualitatif deskriptif dimana penulis menggunakan penjabaran melalui kata - kata untuk menjelaskan analisis yang dilakukan. Pengumpulan data dilakukan melalui kombinasi antara studi pustaka dan studi kasus dimana penulis kemudian menganalisis kasus yang terjadi dengan konsep konsep dan penjelasan yang didapatkan melalui studi pustaka. Karena itu data yang dikumpulkan terbagi menjadi tiga, yaitu data primer, data sekunder, dan sebuah fenomena nyata dari studi kasus. Data Primer berasal dari pernyataan resmi atau isi dari konvensi internasional dan juga regulasi yang ada di Indonesia sedangkan data sekunder berupa penelitian kepustakaan dengan cara mengkaji buku - buku, jurnal, hasil penelitian, serta melalui media internet yang penulis anggap berkenaan dengan hal yang berhubungandengan permasalahan penelitian.

Objek utama dari penelitian ini adalah Indonesia, dimana Indonesia adalah sebuah entitas sosial yang memiliki kewajiban dalam pemnuhak hak asasi manusia. Justifikasi ini diperkuat dengan ratifikasi yang dilakukan oleh Indonesia. Indonesia penulis jadikan objek utama karena Indonesia memiliki angka yang sangat tinggi terkait pekerja migran yang bekerja di negara asing.

Penulis juga menggunakan sudut pandang dari konvensi internasioanl tentang hak buruh yang kemudian menjadi tolak ukur untuk melihat sejauh mana Indonesia berhasil dalam memberikan hak untuk pekerja migrannya. Dalam konvensi ini juga terdapat konsep yang penulis jelaskan di kerangka pemikiran mengenai hak buruh yang merupakan turunan dari konsep hak asasi manusia.

\section{Hasil dan Pembahasan}

\section{Dinamika Indonesia dalam Menjamin Hak Para Pekerja Migran Di Singapura}

Negara Kesatuan Republik Indonesia (NKRI) merupakan negara berkembang yang terus mengupayakan sistem pembangunan, salah satunya adalah pembangunan nasional di bidang ekonomi. Pembangunan nasional dilaksanakan dengan tujuan untuk mewujudkan masyarakat yang sejahtera, adil, makmur dan merata, baik secara material maupun spiritual. Di Indonesia hak untuk mendapatkan pekerjaan merupakan hak yang dijamin oleh konstitusi, hal ini di atur dalam Pasal 
Implementasi Konvensi Internasional Tentang Perlindungan Hak Pekerja Asing dan Anggota Keluarganya: Studi Kasus Penjaminan Hak Pekerja Migran Indonesia di Singapura

27 ayat 2 Undang-Undang Dasar 1945. Walaupun demikian, tidak dapat dipungkiri bahwa ketersediaan lapangan pekerjaan bagi seluruh pencari kerja masih kurang di dalam negeri, untuk itu banyak dari mereka yang mencoba untuk mendapatkan pekerjaan di luar negeri. Salah satu negara tujuan warga negara Indonesia dalam mencari pekerjaan adalah Singapura.

Dalam penelitian ini, penulis mengutip laporan resmi yang dikeluarkan oleh sebuah organisasi non-pemerintah dan badan amal yang berbasis di Singapura, yaitu HOME dan TWC2. The Humanitarian Organization for Migration Economics (Organisasi Kemanusiaan untuk Ekonomi Migrasi/HOME) adalah sebuah organisasi non-pemerintah yang berbasis di Singapura yang melayani kebutuhan masyarakat migran, terutama pekerja migran dengan upah rendah. Didirikan pada tahun 2004, HOME telah diberikan status ECOSOC oleh PBB dan memberikan layanan kepada ribuan pekerja migran yang membutuhkan melalui penyediaan penampungan, bantuan hukum, pelatihan dan program-program rehabilitasi. Sedangkan, Transient Workers Count Too atau TWC2 adalah badan amal yang terdaftar di Singapura yang memperjuangkan perlakuan yang adil terhadap pekerja migran kerah-biru dan pekerja rumah tangga migran. Badan amal ini melakukan pekerjaan advokasi, melakukan penelitian, dan menyediakan berbagai bantuan kepada para pekerja migran yang mengalami kecelakaan di tempat kerja atau dieksploitasi oleh majikan dan agen tenaga kerja.

HOME dan TWC2 telah memanfaatkan berbagai sumber informasi di dalam organisasi mereka untuk menyusun sejumlah pernyataan dan rekomendasi yang dituangkan di dalam laporan ini. Ini termasuk data survei, data kasus, wawancara pribadi dengan para pekerja rumah tangga Indonesia, dan pengumpulan pengalaman para pekerja sosial dan pekerja sukarela penulis. Dalam penyusunan laporan ini, HOME dan TWC2 juga mengadakan konsultasi dengan para pekerja rumah tangga migran Indonesia di bulan Juli 2017, 30 pekerja rumah tangga berpartisipasi, termasuk beberapa perwakilan dari Indonesian Family Network. Kedua organisasi tersebut juga mengacu pada literatur akademis yang relevan dan laporan media tentang pekerja rumah tangga migran. Ada sebanyak 239.700 pekerja 
rumah tangga migran di Singapura pada bulan Desember 2016. Sebuah Straits Times di bulan Mei 2016 menyatakan bahwa ada sebanyak 125.000 pekerja rumah tangga migran Indonesia di Singapura, dengan Indonesia sebagai negara dengan sumber terbesar.

Kedua organisasi tersebut mengeluarkan sebuah laporan di tahun 2017 yang diserahkan untuk sesi ke-27 Komite PBB untuk pekerja migrant. Hasil laporan tersebut memuat beberapa pelanggaran terhadap ICRMW yang dilakukan oleh Indonesia. Adapun pelanggaran-pelanggaran tersebut dibagi menjadi 6 kelompok besar, yakni:

a. Kegagalan Dalam Mengatur Agen-Agen Rekrutmen Di Negara Asal Pekerja rumah tangga Indonesia seringkali direkrut di negara asal mereka melalui berbagai saluran resmi dan tidak resmi (agen-agen tanpa izin). Hal ini melanggar Pasal 66 Ayat 2 dari Konvensi yang menyatakan bahwa pihak berwajib di Indonesia harus memberikan wewenang, menyetujui dan mengawasi perantara (baik badan pemerintah maupun swasta) yang terlibat di dalam perekrutan warganya untuk bekerja di luar negeri.

Pemerintah Indonesia juga bermitra dengan sejumlah bank dan agen perekrutan untuk memberikan pinjaman uang kepada para pekerja rumah tangga untuk membantu mereka melunasi biaya agen. Dengan skema ini, seorang pekerja rumah tangga Indonesia akan mengambil pinjaman pribadi dengan jumlah sekitar S\$1.700 dari Maybank Indonesia untuk biaya pelatihan, pembuatan paspor, cek medis dan biaya penempatan untuk agen-agen Indonesia. Pekerja rumah tangga migran yang mengambil pilihan ini tetap harus membayar biaya layanan terpisah kepada agen-agen Singapura dengan biaya sebesar $\mathrm{S} \$ 1.000$, namun tidak dikenakan biaya transfer bila mereka berganti majikan . Meskipun skema ini diterapkan untuk membatasi biaya dan meningkatkan transparansi, keluarga para pekerja rumah tangga masih menghadapi resiko apabila pekerja tersebut melanggar kontrak kerja dan/atau gagal membayar pinjamannya. HOME dan TWC2 telah menemukan banyak laporan tentang pekerja rumah tangga dan keluarga mereka yang mendapatkan ancaman dan pelecehan oleh agen-agen Indonesia karena gagal memenuhi kewajiban atas pinjaman mereka. 
Implementasi Konvensi Internasional Tentang Perlindungan Hak Pekerja Asing dan Anggota Keluarganya: Studi Kasus Penjaminan Hak Pekerja Migran Indonesia di Singapura

Pekerja rumah tangga migran yang ingin menghindari sistem perekrutan eksploitatif ini tidak diperbolehkan karena praktik "perekrutan langsung" tidak diizinkan di bawah hukum Indonesia.

b. Orientasi dan Pelatihan Pra Keberangkatan

Meskipun Pasal 33 dan Pasal 37 Konvensi menetapkan bahwa Negara Asal harus menjamin seluruh pekerja migrannya mendapatkan informasi sepenuhnya tentang hak dan kewajiban hukum mereka sebelum mereka berangkat keluar negeri, sebagaimana kondisi penerimaan dan tempat tinggal di Negara Tempat Kerja, para pekerja rumah tangga migran Indonesia seringkali tidak tahumenahu mengenai hak-hak mereka. Selain itu, tidak ada tindak lanjut dari perekrut Indonesia mengenai kesejahteraan mereka begitu pekerja rumah tangga migran tiba di Singapura. Ketika masalah timbul, agen-agen ini tidak menunjukkan minat yang besar untuk melindungi pekerja mereka, dan hanya tertarik untuk memperoleh kembali hutang yang dikeluarkan oleh pekerja. Sejumlah besar pekerja rumah tangga migran melaporkan kekerasan verbal dan ancaman dari perekrut mereka di Indonesia ketika mereka mengeluhkan tindak kekerasan dan eksploitasi oleh majikan mereka di Singapura. Pekerja rumah tangga migran sering diberi informasi yang tidak memadai dan/atau tidak akurat mengenai syarat kerja mereka dan sifat pekerjaan yang harus mereka laksanakan. Banyak pekerja rumah tangga migran melaporkan bahwa beban kerja mereka lebih besar dari apa yang telah mereka sepakati (sebagai contoh, ukuran rumah atau rumah tangga lebih besar dari apa yang telah diberitahukan kepada mereka), sementara sejumlah pekerja lain melaporkan periode pemotongan gaji yang diperpanjang.

Pusat-pusat pelatihan ini seringkali dalam kondisi yang buruk, di mana para pekerja juga sering melaporkan bahwa mereka hanya diberikan makanan berupa mi instan dan nasi putih. Tidak ada kebebasan bergerak karena mereka dilarang meninggalkan pusat pelatihan; Selain itu, beberapa pusat pelatihan tidak mengizinkan kunjungan dari anggota keluarga. Banyak pekerja rumah tangga yang dipaksa untuk memotong pendek rambut mereka. Banyak pula laporan 
mengenai area untuk tidur yang penuh sesak tanpa adanya kasur. Banyak yang tidak memahami isi kontrak yang mereka tandatangani di Indonesia, karena kontrak tersebut ditulis dalam Bahasa Inggris dan isinya tidak dijelaskan kepada mereka; sebagian dari mereka bahkan melaporkan bahwa mereka disuruh menandatangani kontrak kosong. Banyak pekerja yang melaporkan bahwa mereka tidak diperbolehkan oleh rekruter mereka untuk mengajukan terlalu banyak pertanyaan. Para pekerja rumah tangga juga tidak diberikan ruang untuk negosiasi mengenai kondisi kerja yang lebih baik, misalnya mengenai hari istirahat.

c. Sistem Komputerisasi Pekerja Migran Indonesia (Computerized System of Indonesia Migrant Workers / CSIMW)

Banyak pekerja migran yang tidak tahu mengenai adanya CSIMW, yang menurut laporan kenegaraan pemerintah Indonesia dimaksudkan untuk mengumpulkan "data akurat dan terpadu mengenai penempatan pekerja migran" untuk meningkatkan perlindungan mereka. Hal ini menyatakan bahwa CSIMW akan memuat data para pekerja migran yang terkait dengan proses rekrutmen, termasuk agen-agen perekrutan mereka, pusat-pusat pelatihan, fasilitas-fasilitas medis di mana mereka menjalani pemeriksaan kesehatan, asurasi, sertifikasi, lembaga keuangan serta 6 utusan-utusan Indonesia di luar negeri. Namun, para pekerja rumah tangga migran yang penulis hubungi mengatakan bahwa mereka tidak tahu atau bingung mengenai sistem ini dan manfaatnya.

d. Gagal dalam Menyesuaikan Lokasi Tujuan Pekerja Migran

Walaupun pemerintah Indonesia telah menandatangani beberapa perjanjian bilateral dengan Singapura untuk memajukan kepentingan ekonominya, saat ini pemerintah Indonesia tidak memiliki nota kesepahaman dengan Singapura terkait dengan perlindungan dan penempatan pekerja migran. Di dalam laporan kenegaraannya, Indonesia menyebutkan peluncuran Kartu Pekerja IndonesiaSingapura (KPIS). Namun, terdapat kekurangan informasi yang tersedia untuk para pekerja rumah tangga di Singapura mengenai maksud adanya kartu ini serta manfaat dan keuntungan potensial yang diberikannya kepada pekerja 
Implementasi Konvensi Internasional Tentang Perlindungan Hak Pekerja Asing dan Anggota Keluarganya: Studi Kasus Penjaminan Hak Pekerja Migran Indonesia di Singapura

rumah tangga Indonesia. Para pekerja tersebut menanggapi kartu ini dengan skeptis dan mempertanyakan mengapa migran profesional Indonesia tidak diberikan kartu ini. Mereka pada umumnya memandang kartu ini sebagai alat yang akan membuat mereka rentan terhadap pemerasan dan diskriminasi karena mereka akan dengan mudah diidentifikasi sebagai pekerja rumah tangga. Para pekerja yang mengalami kekerasan dan eksploitasi dan kembali ke negara asalnya telah menghadapi rintangan birokrasi yang sulit mereka atasi dalam usaha mereka untuk mengklaim manfaat yang seharusnya diberikan kartu tersebut.

e. Potensi untuk Terjadinya Perdagangan Manusia Dan Kerja Paksa

Organisasi Buruh Internasional (International Labour Organization/ILO) telah mengidentifikasi 11 indikator kerja paksa, termasuk penyalahgunaan kerentanan, penipuan, pembatasan pergerakan, isolasi, penyimpanan dokumendokumen identitas, kekerasan fisik dan seksual, penahanan gaji, intimidasi dan ancaman, penjeratan hutang, kondisi hidup dan kerja yang tidak pantas, serta lembur yang berlebihan. Pekerja rumah tangga migran Indonesia rentan terhadap sebagian besar dari indikator-indikator ini. Masalah masalah yang sering terjadi seperti; rendahnya gaji yang diberikan,kurangnya libur,waktu bekerja yang terlalu lama,adanya kekerasan,pebatasan komunikasi,penahanan dokumen pribadi,banyaknya ancaman dan intimidasi,makanan yang tidak pantas serta banyak lagi yang mencerminkan bahwa mereka tidak dalam kondisi yang baik. Hal-hal tersebut telah melanggar Pasal 10 Konvensi, dimana kondisi-kondisi yang disebutkan di atas adalah serupa dengan kerja paksa, maka hal-hal di atas juga berisiko melanggar persyaratan yang ditetapkan di dalam Pasal 11. Walaupun tindak-tindak kekerasan tersebut terjadi di Negara Tempat Bekerja, kegagalan Indonesia dalam mengikutsertakan Singapura untuk memperbaiki kondisi pekerjaan para pekerja rumah tangga dan untuk menghilangkan kekerasan merupakan pelanggaran terhadap Pasal 64 Konvensi tentang kewajiban untuk berkonsultasi dan bekerja sama. 
f. Kegagalan Indonesia Dalam Melindungi Dan Menyediakan Fasilitas

Selama berada di luar negeri, bahkan ketika masih berada di dalam penampungan menunggu keberangkatan ke luar negeri, ada kalanya sebagian dari pekerja migran Indonesia menghadapi masalah yang merugikan pekerja migran Indonesia tersebut. Persoalannya adalah apa penyebab munculnya masalah, dan bagaimana kadar masalah yang dihadapi tersebut, serta seberapa banyak pekerja migran Indonesia yang mengalaminya serta instansi Pemerintahan mana yang harus menangani hingga melakukan penyelesaian masalah baik sebelum maupun sesudah penempatan di luar negeri. Hal ini penting untuk dipertimbangkan dengan menggunakan pemikiran positif agar tidak muncul kesan bahwa seakan-akan semua pekerja migrant mengalaminya, sehingga tidak jarang muncul pendapat yang menggugat program penempatan pekerja migran di luar negeri dan meminta agar pemerintah menghentikannya. Masalah yang muncul pada awalnya ialah dokumentasi hingga kurang cakapnya pengetahuan dimiliki calon pekerja migrant mengenai hal yang dipersiapkan sebelum penempatan (yang mana ini merupakan masalah teknis), di samping itu diindikasikan adanya permainan oknum dari instansi terkait dalam proses prapenempatan calon pekerja migrant tersebut. Selain itu, masalah-masalah lain juga masuk dalam laporan, yakni:

1. Bantuan Di Negara Tempat Bekerja

Indonesia telah menyatakan di dalam laporannya bahwa mereka mengadakan program-program pelatihan tahunan untuk para petugas konsuler dalam mengatasi isu-isu yang terkait dengan 8 perdagangan manusia, akses terhadap keadilan, dan hak-hak asasi manusia. IFN dan sejumlah kelompok lain bertemu dengan staf konsuler setiap triwulan. Namun, para pekerja rumah tangga migran berbagi pengalaman mereka kepada HOME dan TWC2 mengenai perlakuan-perlakuan bias oleh beberapa staf kedutaan garis depan, sementara para profesional mendapatkan perlakuan lebih sopan dan lebih hormat oleh para staf dibandingkan dengan pekerja rumah tangga. Para pekerja rumah tangga migran telah melaporkan bahwa mereka diberitahu oleh staf dan petugas 
Kedutaan bahwa mereka seharusnya tidak boleh mengeluhkan kondisi mereka karena mereka "beruntung" mendapatkan pekerjaan di Singapura. Selain itu, hotline kedutaan seringkali sibuk atau tidak dijawab. Selama mediasi, petugas kedutaan biasanya menyerahkan tanggung jawab penyelesaian perselisihan mengenai pekerjaan pekerja rumah tangga migran ke pihak agen-agen Singapura, sementara petugas kedutaan tersebut tidak memainkan peran yang lebih aktif. Para petugas dan pejabat juga seringkali memaksa para pekerja untuk pulang ke negara asal mereka sebagai solusi atas masalah mereka, dan tidak berjuang untuk menjamin hak-hak pekerja tersebut di Singapura.

Peran Indonesia dalam melindungi WNI tercermin dalam tujuan negara yang ada pada pembukaan UUD 1945 alinea keempat yaitu melindungi segenap bangsa Indonesia dan seluruh tumpah darah Indonesia, untuk itu peran negara dalam melindungi pekerja migran yang merupakan warga negara Indonesia yang bekerja diluar negeri sangat perlu untuk memberikan jaminan keselamatan warga negara meskipun berada diluar negeri. Berdasarkan data dari Crisis Center BNP2TKI permasalahan yang diterima ada 121 jenis pengaduan di Singapura. Pengaduan terbanyak adalah putus hubungan komunikasi. Dengan begitu banyaknya pengaduan yang diterima perlu adanya peran pemerintah Indonesia dalam melindungi pekerjamigran Indonesia di Singapura lewat Kemnaker dan BNP2TKI sebagai kementerian dan badan yang kompeten dalam bidang ketenagakerjaan dan juga peran kedutaan besar di Singapura atau KBRI Singapura sebagai perwakilan Indonesia di Singapura.

Petugas konsulat di Kedutaan Besar Indonesia menangani sebagian besar layanan perlindungan pekerja migran di Singapura. Fungsi mereka adalah melindungi kepentingan WNI (termasuk pekerja migran) dan perusahaan swasta Indonesia yang beroperasi di Singapura. Petugas konsulat di Kedutaan Besar di Singapura menyediakan layanan umum harian bagi WNI (termasuk PRT) lewat telepon, SMS dan jalur komunikasi 
cepat dan langsung (hotline) 24 jam untuk konseling dan penanganan keluhan bagi WNI. Lebih dari 70 persen PRT Indonesia yang melaporkan kasus mereka ke kedutaan menemui masalah pada minggu pertama mereka bekerja, termasuk upah yang tidak dibayarkan dan kasus kekerasan.

2. Standar Kontrak

Kedutaan Besar Republik Indonesia telah membuat kontrak kerja standar dengan tujuan melindungi hak-hak pekerja, namun ketentuanketentuannya tidak sesuai dengan standar ketenagakerjaan internasional. Tidak ada ketentuan-ketentuan mengenai hari libur nasional, batasan jam kerja, serta standar-standar akomodasi. Selain itu, walaupun ada ketetapan bahwa pekerja berhak atas empat hari libur atau istirahat dalam sebulan, namun ketiadaan ketentuan (mengenai hari libur umum) tersebut membuat majikan memilih untuk memberikan kompensasi finansial kepada pekerja sebagai pengganti hari-hari libur tersebut.

3. Fasilitas di Kedutaan

Baik mantan staf kedutaan maupun para pekerja rumah tangga yang telah tinggal di tempat penampungan kedutaan telah mengkritik tempat penampungan ini karena tidak menyediakan makanan yang cukup; menyita telepon genggam, mengakibatkan pekerja rumah tangga migran tidak dapat menghubungi keluarga mereka; dan membatasi pergerakan para pekerja rumah tangga migran tersebut dengan tidak mengizinkan mereka keluar dari tempat penampungan. Tempat penampungan ini, sebagaimana dilaporkan, seringkali penuh sesak, dan staf kedutaan bersikap kasar terhadap penghuni tempat penampungan. Pekerja rumah tangga migran juga melaporkan bahwa tempat penampungan tersebut kekurangan staf, di mana seorang pekerja rumah tangga migran yang tinggal di tempat penampungan tersebut selama lebih dari dua bulan dalam tahun ini mengatakan bahwa kelihatannya hanya terdapat dua orang yang mengurus lebih dari 150 perempuanpekerja rumah tangga migran. Hal tersebut merupakan pelanggaran Pasal 64 Konvensi (konsultasi dan kerja sama dengan maksud 
Implementasi Konvensi Internasional Tentang Perlindungan Hak Pekerja Asing dan Anggota Keluarganya: Studi Kasus Penjaminan Hak Pekerja Migran Indonesia di Singapura

memajukan kondisi manusiawi bagi pekerja), dan Pasal 65 Bagian 2 tentang penyediaan layanan konsuler dan layanan-layanan lainnya yang memadai.

Terbatasnya jumlah SDM di Kedutaan Besar Indonesia membuat mereka tidak mampu menghadapi masalah dan melayani banyaknya jumlah PRT Indonesia yang mencari bantuan. Akibatnya, Kedutaan Besar gagal memberikan perlindungan optimal kepada PRT. Hingga saat ini, Kedutaan Besar tidak memiliki standar pengelolaan kasus maupun indikator transparan kesuksesan. Dalam kasus-kasus yang berdampak sosio-politis yang signifikan bagi hubungan Indonesia dan Singapura seperti pembunuhan, perlakuan kejam, perkosaan yang diikuti oleh penyiksaan dan kematian, memang Kedutaan Besar bekerjasama dengan pihak penguasa Singapura. Kedutaan cenderung menyelesaikan masalah yang berkaitan dengan tenaga kerja atau kekerasan yang tidak terlalu serius lewat jalur negosiasi atau mediasi karena rumitnya jalur hukum di Singapura. Dalam kasus-kasus seperti ini, kedutaan berupaya memberikan tekanan kepada majikan atau agen untuk menghormati hak-hak PRT. Majikan atau agen yang melanggar hukum jarang sekali dikenakan sanksi oleh Kementerian Tenaga Kerja. Bila agen dan majikan memenuhi permintaan kedutaan maka mereka dibebaskan dari segala sanksi, namun bila kasus ditangani oleh Kementerian Tenaga Kerja maka majikan yang melanggar ijin kerja tidak akan diberikan ijin umtuk mempekerjakan PRT asing. Dengan demikian, nasib PRT sangatlah tergantung pada kedutaan. PRT memiliki kekhawatiran besar mengenai penyelesaian kasus mereka mengingat sedikitnya jumlah personil kedutaan dan besarnya volume kerja yang ada. PRT yang tinggal di tempat penampungan pemerintah akibat menunggu penyelesaian kasus diminta untuk tetap tinggal di Singapura hingga masalah tuntas.

4. Fasilitas Untuk Migran Yang Pulang

Banyak pekerja rumah tangga migran yang menyatakan keprihatinan mengenai kesempatan kerja bagi mereka saat kembali ke 
Indonesia. Ada persepsi yang meluas bahwa pemerintah Indonesia tidak berbuat banyak untuk membantu pekerja rumah tangga migran, khususnya dalam menyediakan peluang bisnis dan pekerjaan yang memadai yang dapat menjamin kehidupan yang layak bagi para migran yang pulang dan keluarga mereka. Tanpa alternatif-alternatif ini, pekerja rumah tangga migran seringkali merasa bahwa mereka tidak memiliki banyak pilihan kecuali mencari pekerjaan di luar negeri lagi untuk menafkahi keluarga mereka dan mencapai mobilitas sosial-ekonomi. Hanya sedikit peserta kelompok fokus yang tahu mengenai adanya program-program reintegrasi pemerintah, yang mencerminkan kurangnya publisitas atas programprogram tersebut. Upaya untuk melindungi keluarga pekerja juga terbatas. Pekerja rumah tangga migran yang dipecat secara tidak adil dan/atau mengalami kekerasan oleh majikan dan/atau agen perekrut mereka, serta mereka yang pulang ke negara asal dengan masalah medis, tetap tidak mendapatkan kejelasan mengenai cara untuk mendapatkan keadilan dan mengklaim kompensasi di saat kepulangan mereka. Hal ini melanggar Pasal 67, yang mencantumkan bahwa Negara Pihak harus bekerja sama untuk memajukan "kondisi-kondisi ekonomi yang memadai" bagi pekerja migran untuk pemukiman kembali, termasuk memfasilitasi "reintegrasi sosial dan budaya yang tahan lama" di negara asal mereka.

2. Kasus Penganiyayaan dan Penelantaran PMI Asal Ponorogo

Laporan dari organisasi HOME dan TWC2 mengenai kegagalan Indonesia dalam menjamin hak pekerja migran mulai dari perekrutan hingga penanganan masalah di KBRI Singapura seakan diperjelas oleh banyaknya kasus penyiksaan yang terjadi pada pekerja-pekerja migrant asal Indonesia. Salah satu kasus adalah penyiksaan dan penelantaran PMI asal Ponorogo, Fadila Rahmawati. Kasus ini terjadi pada bulan Januari tahun 2017. Fadila Rahmawati mengaku selama bekerja 10 bulan di Singapura, dia sering mendapat perlakuan kasar dari majikannya, seperti dipukuli dan bahkan disterika. Fadila juga mengaku bahwa dirinya juga sering kali harus 
tetap bekerja selama 24 jam. Perlakuan kasar lainnya dari majikan Fadila adalah tidak memberi makanan selama beberapa hari. Setelah mengalami penyiksaan selama 10 bulan, Fadila kemudian dibuang ke Batam oleh majikannya. Untungnya, Fadila ditemukan oleh seorang anggota TNI dan kemudian dibantu untuk pulang ke Ponorogo. Menurut keterangan dari Kepala Urusan Pemerintahan Desa Sukorejo, kasus penyiksaan Fadila Rahmawati sudah dicoba untuk dibantu diperjuangkan hak-haknya melaui jalur hukum, namun ternyata Fadila merupakan pekerja yang direkrut oleh agen illegal di Surabaya sehingga namanya tidak terdaftar secara resmi. Saat direkrut pun Fadila sebenarnya belum cukup umur, sehingga belum paham secara detail mengenai pekerjaannya dan datanya mudah unutk dimanipulasi olh agen perekrut.

Saat tiba di Ponorogo, Fadila dalam kondisi yang memprihatinkan dengan tubuh kurus dan penuh luka Kondisi psikologisnya pun tergannggu. Hal ini menyebabkan perawatan Fadila yang semula berada di rumah sakit umum harus dipindahkan ke rumah sakit jiwa karena kondisi mental yang kurang stabil. Kasus Fadila menambah daftar panjang korban perdagangan manusia, kemiskinan dan sempitnya lapangan kerja, sehingga sebagian warga Indonesia bekerja di luar negeri. Bukan hanya dipalsukan dokumennya, namun Fadila juga menjadi korban perekrutan tidak prosedural karena tidak terdaftar di Disnakertrans, BNP2TKI. Setelah kondisi Fadila pulih, pihak keluarga dibantu oleh tim pengacara Keluarga Besar Buruh Migran (Kabar Bumi) melaporkan kasus ini sebagai TPPO ke Polda Surabaya. Untuk pelaporan awal, keluarga dari Fadila melaporkan Agen Perekrutan yang merekrut Fadila dan mengirimkannya ke Singapura dengan tuduhan Undang-undang TPPO, Pasal 1 ayat 2. Kepolisian pun telah berkomitmen untuk mencari dan menangkap semua pelaku yang terlibat dalam kasus ini. Menurut pernyataan Erwiana, juru bicara Kabar Bumi, pihaknya sudah berkoordinasi dengan KBRI Singapura dan telah mengajukan perlindungan ke LPSK (Lembaga Perlindungan Saksi dan 
Korban) untuk penanganan dan pendampingan kasus secara hukum. Fadila dan sebagian besar masyarakat pedesaan tidak mengetahui prosedur untuk menjadi BMI (buruh migran Indonesia), banyak dari para BMI hanya mengetahui direkrut oleh calo dan akan dibawa PPTKIS. Semua kepengurusan dilakukan oleh PPTKIS/agen/calo, BMI hanya mengetahui harus membayar dengan potongan gaji yang tinggi selama berbulan-bulan (overcharging), ketika bekerja. Faktanya Sedangkan PPTKIS/agen/calo tidak akan membantu BMI jika mengalami masalah. Seperti halnya kasus yang menimpa Fadila. Permasalahan yang dihadapi oleh korban akan terus terjadi selama perlindungan masih diserahkan kepada pihak swasta.

Agen yang merekrut Fadila dikabarkan hanya memberi uang santunan sebesar Rp 5 juta untuk biaya perawatan. Agen tersebut juga menawarkan surat perjanjian agar tidak menempuh jalur hukum atas kondisi Fadila. Namun tawaran tersebut ditolak oleh pihak keluarga karena menginginkan kasus Fadila tetap diproses karena berdasarkan hasil penelusuran Kementrian Tenaga Kerja, kasus ini merupakan tindakan human trafficking atau perdagangan orang.

\section{Kesimpulan}

Mendapatkan pekerjaan merupakan hal yang penting dalam kehidupan manusia. Hak untuk mendapatkannya pun telah diatur dalam Undang-undang. Berbagai lapangan pekerjaan yang berbeda pun juga tersedia untuk para pencari kerja. Bahkan jika tidak dapat menemukan pekerjaan di dalam negeri pun, para pencari kerja bisa mencari dan mendapatkan pekerjaan di luar negeri. Hal ini secara langsung menuntut pemerintah untuk memfasilitasi dan memberi perlindungan hak bagi para pekerja tersebut. Atas kesadaran adanya perlindungan hak bagi para pekerja asing ini, maka diadakanlah sebuah konvensi internasional yang khusus untuk membahas perlindungan hak pekerja asing, yakni ICRMW. Dengan adaya konvensi tersebut, seorang pekerja asing tentunya tidak perlu lagi merasa takut bila haknya saat bekerja di luar negeri terancam atau dilanggar, terlebih jika negara 
Implementasi Konvensi Internasional Tentang Perlindungan Hak Pekerja Asing dan Anggota Keluarganya: Studi Kasus Penjaminan Hak Pekerja Migran Indonesia di Singapura

asalnya telah meratifikasi konvensi tersebut, sehingga adanya aturan yang jelas secara hukum untuk melindungi haknya dan hak keluarganya.

Namun sayangnya, masih saja terdapat kelalaian pada pemerintah dalam menjamin keamanan para pekerja asing. Seperti halnya yang terjadi pada pekerja asing asal Indonesia yang berada di Singapura. Masalah bahkan belum sampai pada isu perbudakan, melainkan perekrutan yang dirasa belum transparan. Kesaksian dari para pekerja Indonesia yang berada di Singapura menjadi bukti nyata bahwa pemerintah belum bisa sepenuhnya menjamin keamanan pekerja tersebut, bahkan pada proses perekrutan. Tidak jarang juga pekerja asal Indonesia mengalami penganiayaan karena dinilai tidak memiliki skill dalam bekerja. Hal ini karena kurangnya persiapan dan pengalaman sebelum berangkat bekerja ke luar negeri. Salain itu, masalah juga terletak pada maraknya penyalur tenaga kerja illegal sehingga perlindungan hukum tidak bisa diberikan karena mereka tidak terdaftar sebagai pekerja resmi. Oleh karena itu, pemerintah Indonesia perlu memberikan perhatian terhadap masalah-masalah seperti ini. Pemerintah Indonesia harus mempertegas aturan bagi mereka yang ingin bekerja keluar negeri. Selain itu, pemberian pemahaman terlebih dahulu tentang apa yang akan mereka kerjakan, lembaga mana yang bertanggung jawab atas keberangkatan mereka, serta perlindungan hak-hak apa saja yang mereka miliki saat bekerja di luar negeri merupakan hal-hal penting untuk dipahami oleh setiap pekerja asing. Sehingga bila terjadi pelanggaran hak, pekerja tersebut paham apa yang harus dilakukan dan pemerintah pun siap untuk memberikan pembelaan bagi warga negaranya. Kasus dari Fadila Rahmawati merupakan salah satu contoh bagaimana pemahaman masyarakat mengenai bekerja di luar negeri masih belum baik dan penanganan dari negara juga masih terkesan kurang serius. Deretan kasus-kasus penyiksaan PMI seharusnya menjadi pelajaran bagi seluruh lapisan masyarakat akan pentingnya pemahaman dan kesiapan diri sebelum bekerja ke luar negeri. 


\section{Daftar Pustaka}

Abby, Tabrani. 2007. "Pedoman Bantuan Hukum di Indonesia”. Jakarta: YLBHI

Arshad, Arlina dan Seow, Joanna. 'Indonesia Plans to Stop Sending New Live-In Maids Abroad', Straits Times, diakses dari https://www.straitstimes.com/asia/se-asia/indonesia-plans-to-stop-sendingnew-live-in-maids-abroad

Departemen Ketenagakerjaan (Ministry of Manpower), 'Foreign Workforce Numbers', http://www.mom.gov.sg/documents-andpublications/foreignworkforce-numbers

Fambrblum, Basina; Nicolson, Eleanor Taylor dan Paoletti, Sarah. "Akses Buruh Migran Terhadap Keadilan di Negara Asal: Studi Kasus Indonesia" Migran Workers Acces to Justice Series, Open Society Foundation, 2013

International Labour Organization, 'Indicators of Forced Labour', http://www.ilo.org/wcmsp5/groups/public/---ed_norm/--declaration/documents/publication/wcms_203832.pdf

Istanto, Sugeng. 1998. Hukum Internasional. Yogyakarta: Universitas Atma Jaya Jaya , Mega Putra. "Beragam Aduan TKI, Kekerasan Majikan hingga Tak Punya Ongkos Pulang", Detik News, https://news.detik.com/berita/d3664486/beragam-aduan-tki-kekerasan-majikan-hingga-tak-punya-ongkospulang

KOMPAS, "TKI Asal Ponorogo Disiksa Majikan di Singapura lalu Dibuang di Batam”. Diakses dari https://regional.kompas.com/read/2017/01/04/09294211/tki.asal.ponorogo.d isiksa.majikan.di.singapura.lalu.dibuang.di.batam

Konvensi Internasional tentang Perlindungan Hak-Hak Seluruh Pekerja Migran dan Anggota Keluarganya. Diakses melalui https://www.komnasham.go.id/files/1475231394-konvensi-internasionaltentang-\$NEKUF.pdf . Pada tanggal 13 Desember 2019

Koran Perjuangan. "Fadila Rahmatika, TKI yang Disiksa Majikannya", diakses dari https://www.koranperdjoeangan.com/fadila-rahmatika-tki-yang-disiksamajikannya/

Laporan Awal Republik Indonesia tentang Pelaksanaan Konvensi Internasional tentang Perlindungan Hak-hak Semua Pekerja Migran dan Anggota Keluarganya Sesuai dengan Prosedur Pelaporan yang Disederhanakan, 2017, hal.7, paragraf 17. Diakses dari https://tbinternet.ohchr.org/Treaties/CMW/Shared\%20Documents/IDN/CM W_C_IDN_1_6902_E.pdf

Muhtaj, Majda El. Dimensi-dimensi HAM (Mengurangi Hak Ekonomi, Sosial dan Budaya). Jakarta: PT. Raja Grafindo Persada, 2008 
Implementasi Konvensi Internasional Tentang Perlindungan Hak Pekerja Asing dan Anggota Keluarganya: Studi Kasus Penjaminan Hak Pekerja Migran Indonesia di Singapura

Seow, Joanna. 'Compulsory Finance Scheme for Indonesian Maids', Straits Times, 24 June 2016, diakses dari https://www.straitstimes.com/singapore/compulsory-finance-scheme-forindonesian-maids

Smith, Rhona K.M. 2008. "Hukum Hak Asasi Manusia”, Knut D. Asplund (editor), Yogyakarta: PUSHAM UII.

TEMPO. "Cerita TKI Asal Ponorogo Dianiaya Majikannya", diakses dari https://nasional.tempo.co/read/833677/cerita-tki-asal-ponorogo-dianiayamajikannya

United Nations Treaty Collections, International Convention on the Protection of the Rights of All Migrant Workers And The Members of Their Families, diakses dari https://treaties.un.org/Pages/ViewDetails.aspx?src=TREATY\&mtdsg_no=I $\mathrm{V}-13 \&$ chapter $=4 \&$ clang $=$ en 